\title{
Comparative Analysis of Two Inverter Topologies Considering Either Battery or Solar PV as DC Input Sources
}

\author{
Mohammad Ahmad ${ }^{1}$, B. H. Khan ${ }^{2}$, Anil Kumar Jha ${ }^{3}$ \\ ${ }^{1 \& 3}$ Assistant Professor, NIET Greater Noida G.B.Nagar, UP India \\ ${ }_{2}^{2}$ Professor, Aligarh Muslim University Aligarh, UP India
}

\begin{abstract}
In this paper, a comparative analysis of two inverter topologies is carried out for the same RL load. The first topology uses cascaded H-Bridge (CHB) Inverter. The second uses new Multi-level Scheme having Two Level Modules and H-Bridge. Both topologies are studied under two types of input sources: (i) battery and (ii) solar PV panel. The simulation is done in SIMULINK / MATLAB Software. The Total Harmonic Distortion in output load voltage / current and Active / Reactive Powers obtained from both the schemes considering one of the two types of inputs, battery and solar PV panel are compared. It is found that for low input voltage range second scheme is better as it has low THD. And for high input voltage range, first scheme has fewer harmonic. However, the Active power and reactive power are more in new multilevel scheme. As the number of switches is more in cascaded inverter scheme, hence it is costly and has more switching losses for the same input voltage. It is also observed that the results are almost similar for both types of input sources. A capacitor is used across $P V$ panel to reduce spikes in load voltage waveform and hence improve THD.
\end{abstract}

Index Terms: H-Bridge inverter, Level Module (LM), multilevel inverter, Power Quality, Total Harmonic Distortion (THD).

\section{Introduction}

Rising fuel costs, increasing concerns for global climate change and a growing worldwide demand for electricity has led to global efforts towards increasing use of renewable energy sources such as solar, wind, biomass etc. In case of solar PV the energy is harnessed in $\mathrm{dc}$ form. This $\mathrm{dc}$ is converted into grid quality ac and then fed to utility grid or used in isolated load. Various methods are available for dc to ac conversion. Multilevel Inverters have gained popularity in recent times. The power quality gets increasingly better with the number of levels in the output wave. Two topologies for dc to ac conversion are discussed in this paper.

\section{A. Cascaded H Bridge Inverter}

Conventional cascaded multilevel inverter is one of the most important topologies in the family of multilevel and multi-pulse inverters. The cascade topology allows the use of several levels of DC voltages to synthesize a desired AC voltage. The DC levels are considered to be identical since all of them are identical PV modules. H-Bridge Inverter consists of four switches, a dc source and a load across the two arm of H-Bridge. Each switch conducts for a period of $180^{\circ}$. The gate pulses for diagonal switches are identical. A cascaded multi-level inverter consists of a number of $\mathrm{H}$ - Bridge inverter units with separate dc source for each unit and it is connected in cascade as shown in Fig. 1.

\section{Simulation of Cascaded $H$ Bridge Inverter with Battery as a dc source}

Simulation is carried out using SIMULINK/MATLAB software. The variation of delay angles $\alpha$ result in variation of THD in load voltage. For a particular delay angle THD is found to be minimum. Further THD reduction is achieved by increasing the stages of the converter. But after a certain stages, reduction in THD becomes less. Each stage has a fixed dc voltage source of 6 volt. The simulation is done for a fixed RL load having $\mathrm{R}=5 \Omega$ and $\mathrm{L}=5 \mathrm{mH}$.

For single stage case, minimum THD of $29.4 \%$ in load voltage and that of $15.2 \%$ in Load current are obtained for $\alpha=20^{\circ}$. While for two stage, minimum THDs obtained in load voltage and load current are $16.8 \%$ and $4.7 \%$ respectively, for the case when $\alpha 1=15^{\circ}, \alpha 2=45^{\circ}$. As the number of stages of the converter is increased, the level of the output wave is also increased.

For one stage, 3 levels are obtained and for 2 stages, 5 levels are obtained and so on. In general for $\mathrm{m}$ stages in the inverter the number of output levels are $2 \mathrm{~m}+1$.

The simulation is carried out up to 8 stages and the THD obtained in voltage is found to be continuously decreasing with the stages.

The fixed RL considered has $\mathrm{R}=5 \Omega$ and $\mathrm{L}=5 \mathrm{mH}$. 


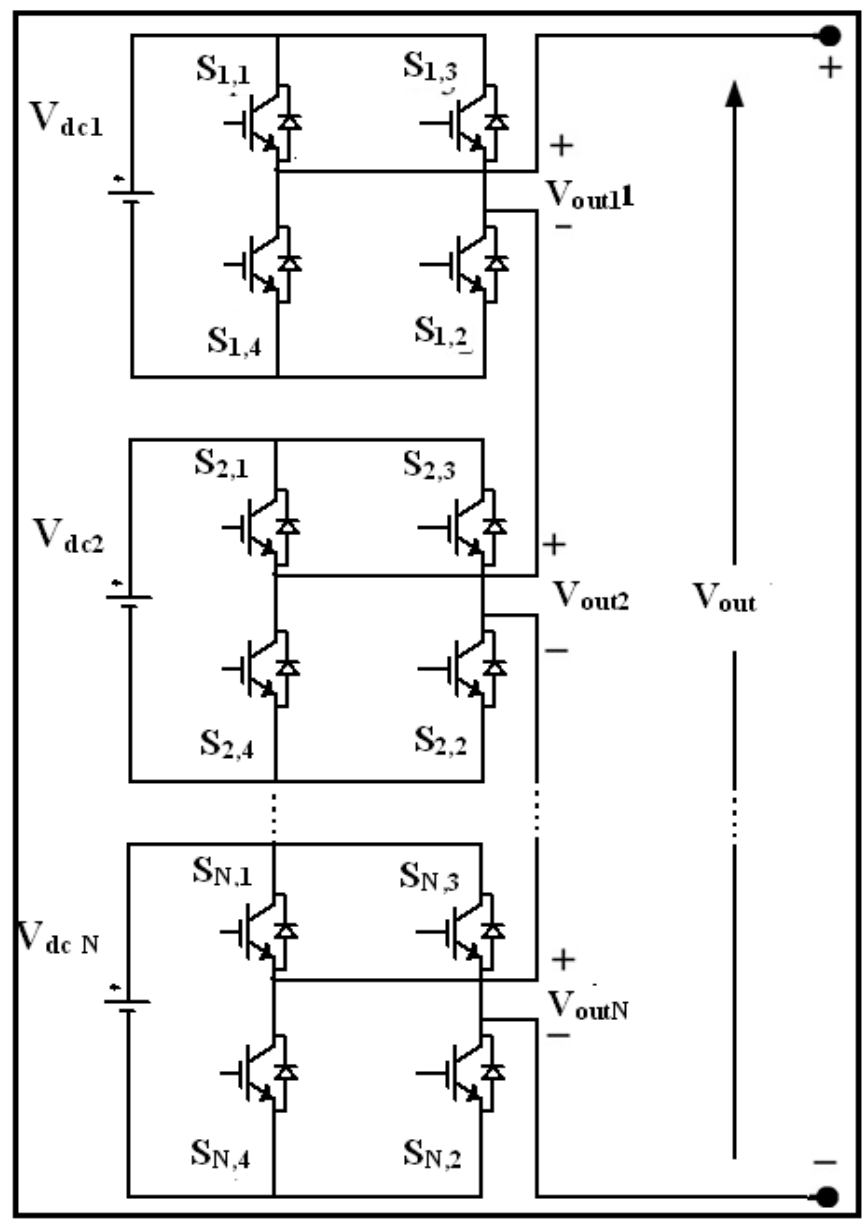

Fig. 1 Cascaded Multilevel H-Bridge Inverter

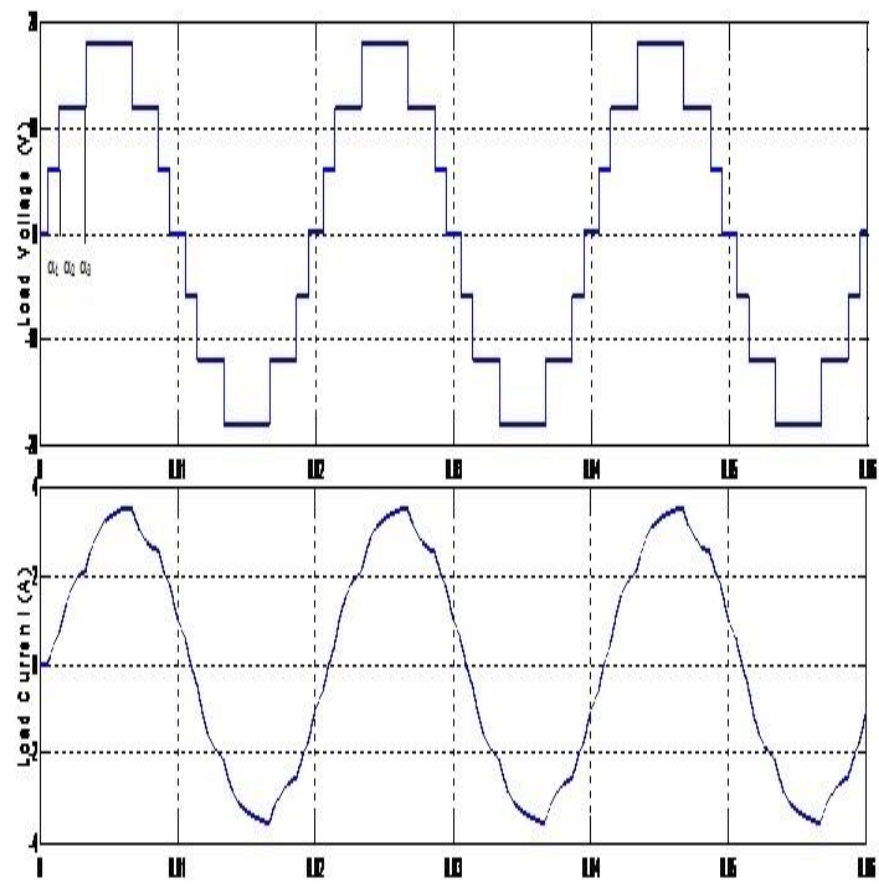

Fig. 2 Load voltage and current waveform for 3 stage CHB Inverter having three delay angles $\alpha 1, \alpha 2 \& \alpha 3$ with battery as dc source 


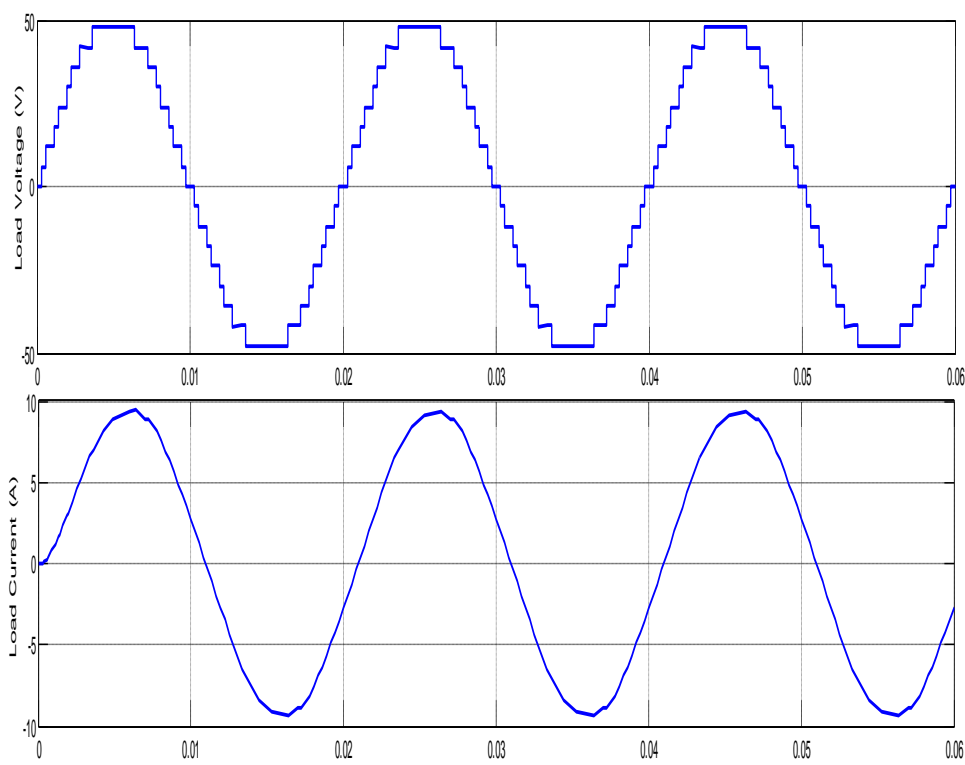

Fig. 3 Load voltage and current waveform for 8 stage CHB Inverter with battery as dc source

For a particular stage number, the variation in delay angles results in variation of THD in voltage and current, Active Power (P) and Reactive power (Q). Table I, shows the variation of THD in load voltage and current, $\mathrm{P} \& \mathrm{Q}$ with different delay angle combination, where $\mathrm{k}$ is the delay angle for kth stage. For a particular delay angle combination, the minimum Load voltage THD and corresponding current THD are highlighted in the table.

TABLE I : Simulation Results For Eight Stage Cascaded H Bridge Inverter With Battery As Dc Source

\begin{tabular}{|c|c|c|c|c|c|c|c|c|c|c|c|c|c|}
\hline \multirow{2}{*}{ 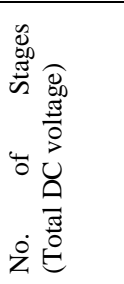 } & \multicolumn{8}{|c|}{ Delay angles } & \multirow{2}{*}{$\begin{array}{l}\text { RMS } \\
\text { Voltage } \\
\text { (Volt) }\end{array}$} & \multirow{2}{*}{$\begin{array}{l}\text { THD } \\
\text { in } \\
\text { Voltage } \\
(\%)\end{array}$} & \multirow{2}{*}{$\begin{array}{l}\text { Activ } \\
\text { e } \\
\text { Power } \\
\mathrm{P}(\mathrm{W})\end{array}$} & \multirow{2}{*}{$\begin{array}{l}\text { Reac } \\
\text { tive } \\
\text { Pow } \\
\text { er } \\
\text { Q( } \\
\text { VAr } \\
\text { ) }\end{array}$} & \multirow{2}{*}{$\begin{array}{l}\text { THD } \\
\text { in } \\
\text { current } \\
(\%)\end{array}$} \\
\hline & 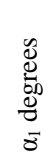 & 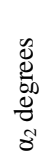 & 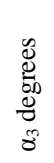 & 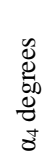 & 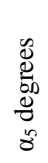 & 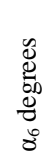 & 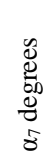 & 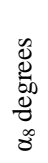 & & & & & \\
\hline \multirow{3}{*}{$\begin{array}{l}1 \\
(\mathrm{~V}=6 \\
\text { volt })\end{array}$} & 15 & & & & & & & & 5.4 & 31.9 & 4.9 & 1.5 & 19.4 \\
\hline & 20 & & & & & & & & 5.3 & 29.4 & 4.7 & 1.4 & 15.1 \\
\hline & 30 & & & & & & & & 4.9 & 31 & 3.9 & 1.2 & 13.2 \\
\hline \multirow{4}{*}{$\begin{array}{l}2 \\
(\mathrm{~V}=12 \\
\text { volt })\end{array}$} & 15 & 30 & & & & & & & 10 & 20.4 & 17.8 & 5.6 & 11.1 \\
\hline & 10 & 30 & & & & & & & 10.2 & 20.1 & 18.2 & 5.7 & 12.1 \\
\hline & 10 & 45 & & & & & & & 9.2 & 17.2 & 15.2 & 4.7 & 5.3 \\
\hline & 15 & 45 & & & & & & & 9.1 & 16.8 & 14.8 & 4.7 & 4 \\
\hline \multirow{4}{*}{$\begin{array}{l}3 \\
(\mathrm{~V}=18 \\
\text { volt })\end{array}$} & 10 & 20 & 50 & & & & & & 13.9 & 13.8 & 35 & 11 & 5.7 \\
\hline & 15 & 30 & 45 & & & & & & 13.8 & 14.3 & 34.2 & 10.7 & 5.5 \\
\hline & 10 & 20 & 45 & & & & & & 14.3 & 13.93 & 36.7 & 11.5 & 6.8 \\
\hline & 10 & 25 & 60 & & & & & & 13 & 13.78 & 30.3 & 9.5 & 3.9 \\
\hline \multirow{4}{*}{$\begin{array}{l}4 \\
(\mathrm{~V}=24 \\
\text { volt })\end{array}$} & 10 & 20 & 30 & 50 & & & & & 18.6 & 10.8 & 62.4 & 19.6 & 4.6 \\
\hline & 5 & 15 & 30 & 50 & & & & & 18.8 & 11.2 & 63.8 & 20.1 & 5.4 \\
\hline & 10 & 25 & 45 & 60 & & & & & 16.8 & 11.8 & 50.8 & 16 & 5 \\
\hline & 15 & 25 & 40 & 60 & & & & & 17 & 12.7 & 52.2 & 16.4 & 4.9 \\
\hline \multirow{4}{*}{$\begin{array}{l}5 \\
(\mathrm{~V}=30 \\
\text { volt })\end{array}$} & 10 & 20 & 30 & 45 & 60 & & & & 1.6 & 8.8 & 84.5 & 26.5 & 2.9 \\
\hline & 5 & 15 & 25 & 40 & 60 & & & & 22.4 & 8 & 90.5 & 28.5 & 0.7 \\
\hline & 5 & 15 & 30 & 40 & 60 & & & & 22.1 & 7.6 & 88.7 & 27.9 & 0.1 \\
\hline & 5 & 15 & 30 & 45 & 60 & & & & 21.8 & 7.7 & 86.2 & 27.2 & 2 \\
\hline \multirow{4}{*}{$\begin{array}{l}6 \\
(\mathrm{~V}=36 \\
\text { volt })\end{array}$} & 5 & 10 & 20 & 30 & 45 & 60 & & & 27 & 7.6 & 132 & 41.4 & 3.2 \\
\hline & 5 & 15 & 25 & 40 & 50 & 60 & & & 25.8 & 7.8 & 120.7 & 38 & 0.9 \\
\hline & 5 & 15 & 25 & 40 & 50 & 65 & & & 25.4 & 7.3 & 116.9 & 36.8 & 1.4 \\
\hline & 5 & 15 & 30 & 40 & 50 & 65 & & & 25.2 & 8.3 & 115 & 36.2 & 2.5 \\
\hline \multirow{3}{*}{$\begin{array}{l}7 \\
(\mathrm{~V}=42 \\
\text { volt })\end{array}$} & 5 & 10 & 15 & 30 & 40 & 50 & 60 & & 30.9 & 7 & 173 & 54.3 & 1.9 \\
\hline & 5 & 10 & 20 & 30 & 40 & 50 & 60 & & 30.7 & 6 & 171.4 & 53.8 & 1.1 \\
\hline & 5 & 10 & 20 & 30 & 40 & 50 & 65 & & 30.2 & 5.6 & 166.8 & 52.4 & 0.4 \\
\hline
\end{tabular}


Comparative Analysis of Two Inverter Topologies Considering Either Battery or Solar PV as DC..

\begin{tabular}{|c|c|c|c|c|c|c|c|c|c|c|c|c|c|}
\hline & 5 & 10 & 20 & 30 & 40 & 55 & 70 & & 29.5 & 6.2 & 158 & 49.6 & 0.9 \\
\hline \multirow{4}{*}{$\begin{array}{l}8 \\
(\mathrm{~V}=48 \\
\text { volt })\end{array}$} & 5 & 10 & 20 & 25 & 35 & 45 & 55 & 65 & 34.2 & 5.5 & 213 & 67 & 1.2 \\
\hline & 5 & 10 & 20 & 25 & 30 & 40 & 55 & 70 & 34.4 & 5.9 & 214.6 & 67.4 & 1.2 \\
\hline & 5 & 10 & 20 & 25 & 35 & 40 & 50 & 65 & 3.5 & 5.4 & 221.6 & 69.6 & 0.9 \\
\hline & 5 & 10 & 20 & 25 & 35 & 45 & 50 & 65 & 34.6 & 5.6 & 217.6 & 68.3 & 1 \\
\hline
\end{tabular}

The THD in load voltage and current with number of stages are shown in figure 4.

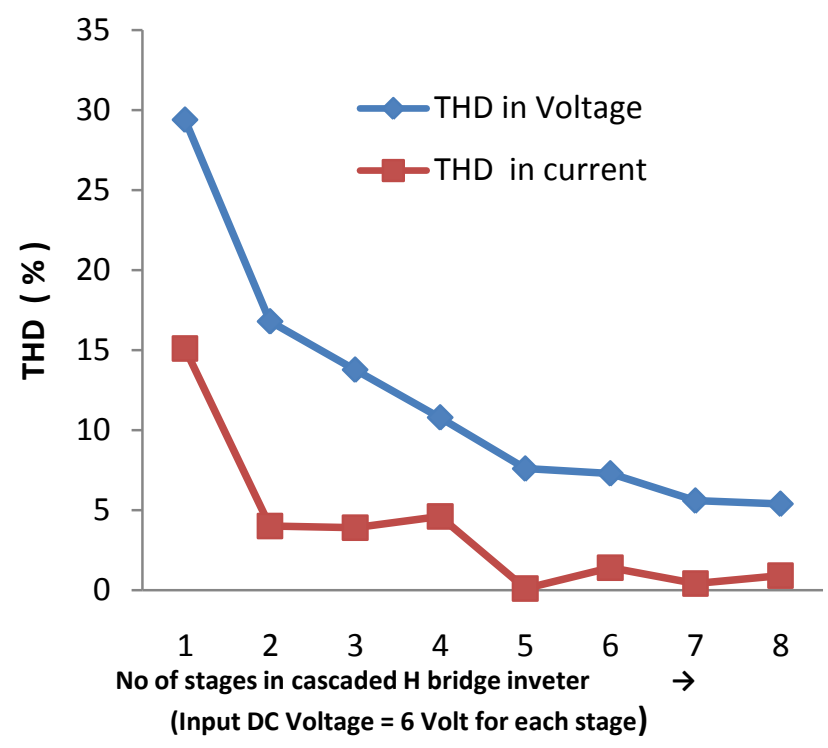

Fig 4 Variation of THD in load voltage and current with the no. of stages in CHB inverter with battery as dc source

Simulation of Cascaded H Bridge Inverter with Solar PV as a de source

The same simulation is after replacing battery with solar PV as dc input and the results are analyzed. Spikes are observed in the output voltage wave, as shown in Fig. 5 [7]. These spikes pose power quality problems. A capacitors (Cs) is used across PV Arrays to reduce these spikes. The suitable value of the capacitor is chosen as

$1 \mathrm{mF}$.
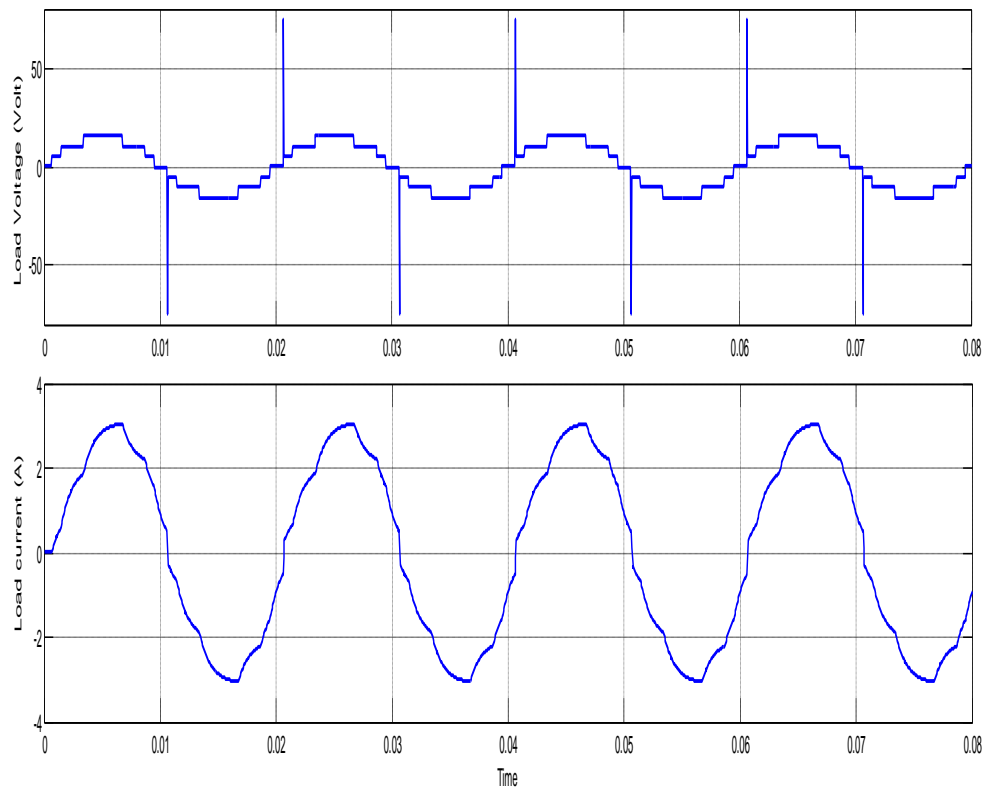

Fig 5. Load voltage and current waveform for 3 stage CHB Inverter with solar PV as dc source without capacitor 

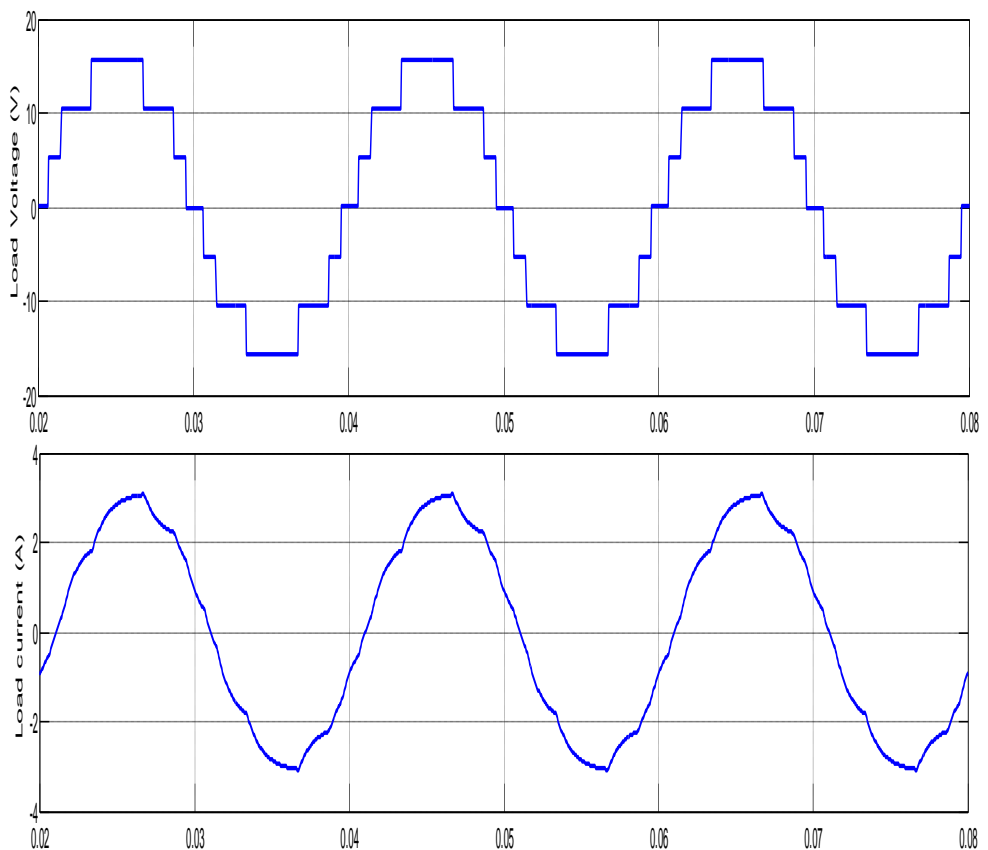

Fig 6. Load voltage and current waveform for 3 stage CHB Inverter with solar PV as dc source with capacitor
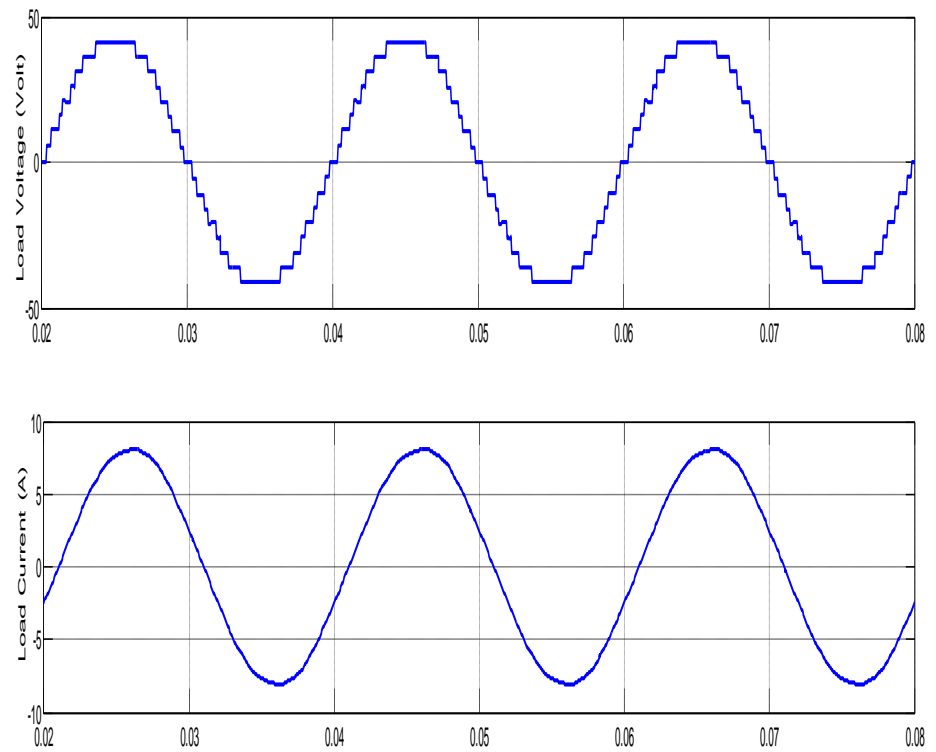

Fig 7. Load voltage and current waveform for 8 stage CHB Inverter with solar PV as dc source

TABLE II: Simulation Results For Eight Stage Cascaded H Bridge Inverter With Solar Pv As Dc Source

\begin{tabular}{|c|c|c|c|c|c|c|c|c|c|c|c|c|c|}
\hline \multirow{2}{*}{ 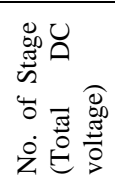 } & \multicolumn{8}{|c|}{ Delay angle } & \multirow{2}{*}{$\begin{array}{l}\text { RMS } \\
\text { Voltage } \\
\text { (Volt) }\end{array}$} & \multirow{2}{*}{$\begin{array}{l}\text { THD } \\
\text { in } \\
\text { Voltag } \\
\text { e (\%) }\end{array}$} & \multirow{2}{*}{$\begin{array}{l}\text { Activ } \\
\text { e } \\
\text { Powe } \\
\text { r } \\
\text { P } \\
\text { (W) }\end{array}$} & \multirow{2}{*}{$\begin{array}{l}\text { Reacti } \\
\text { ve } \\
\text { Power } \\
\text { Q } \\
\text { (VAr) }\end{array}$} & \multirow{2}{*}{$\begin{array}{l}\text { THD } \\
\text { in } \\
\text { current } \\
(\%)\end{array}$} \\
\hline & 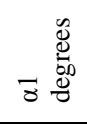 & ช & 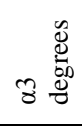 & ष & \% & o d্ঠ் & 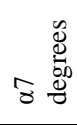 & 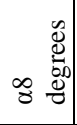 & & & & & \\
\hline \multirow{3}{*}{$\begin{array}{l}1 \\
(\mathrm{~V}=6 \\
\text { volt })\end{array}$} & 15 & & & & & & & & 4.75 & 32 & 3.7 & 1.2 & 19.6 \\
\hline & 20 & & & & & & & & 4.57 & 29.4 & 3.5 & 1.1 & 15.2 \\
\hline & 30 & & & & & & & & 4.23 & 31.1 & 2.9 & 0.93 & 13.4 \\
\hline \multirow{4}{*}{$\begin{array}{l}2 \\
(\mathrm{~V}=12 \\
\text { volt })\end{array}$} & 15 & 30 & & & & & & & 8.7 & 20.2 & 13.3 & 4.2 & 11.2 \\
\hline & 10 & 30 & & & & & & & 8.8 & 20 & 13.6 & 4.2 & 12 \\
\hline & 10 & 45 & & & & & & & 8 & 17.1 & 11.4 & 3.57 & 5.3 \\
\hline & 15 & 45 & & & & & & & 7.9 & 16.8 & 11.15 & 3.5 & 4.7 \\
\hline \multirow{3}{*}{$\begin{array}{l}3 \\
(\mathrm{~V}=18 \\
\text { volt })\end{array}$} & 10 & 20 & 50 & & & & & & 12.1 & 13.8 & 26.1 & 8.2 & 5.6 \\
\hline & 15 & 30 & 45 & & & & & & 12 & 14.3 & 25.6 & 8 & 5.9 \\
\hline & 10 & 20 & 45 & & & & & & 12.4 & 13.9 & 27.5 & 8.6 & 6.7 \\
\hline
\end{tabular}


Comparative Analysis of Two Inverter Topologies Considering Either Battery or Solar PV as DC..

\begin{tabular}{|c|c|c|c|c|c|c|c|c|c|c|c|c|c|}
\hline & 10 & 25 & 60 & & & & & & 11.3 & 13.8 & 22.8 & 7.1 & 4.2 \\
\hline \multirow{4}{*}{$\begin{array}{l}4 \\
(\mathrm{~V}=24 \\
\text { volt })\end{array}$} & 10 & 20 & 30 & 50 & & & & & 16.1 & 10.9 & 46.7 & 14.7 & 4.6 \\
\hline & 5 & 15 & 30 & 50 & & & & & 16.3 & 11.5 & 47.9 & 15 & 6.12 \\
\hline & 10 & 25 & 45 & 60 & & & & & 14.6 & 11.7 & 38.2 & 12 & 5 \\
\hline & 15 & 25 & 40 & 60 & & & & & 14.84 & 10.3 & 39.6 & 12.4 & 3.3 \\
\hline \multirow{4}{*}{$\begin{array}{l}5 \\
(\mathrm{~V}=30 \\
\text { volt })\end{array}$} & 10 & 20 & 30 & 45 & 60 & & & & 18.7 & 8.99 & 63.3 & 19.9 & 3 \\
\hline & 5 & 15 & 25 & 40 & 60 & & & & 19.4 & 8.1 & 68 & 21.3 & 2.9 \\
\hline & 5 & 15 & 30 & 40 & 60 & & & & 19.2 & 7.7 & 66.6 & 20.9 & 1.4 \\
\hline & 5 & 15 & 30 & 45 & 60 & & & & 18.9 & 7.8 & 64.7 & 20.3 & 1.3 \\
\hline \multirow{4}{*}{$\begin{array}{l}6 \\
(\mathrm{~V}=36 \\
\text { volt })\end{array}$} & 5 & 10 & 20 & 30 & 45 & 60 & & & 23.3 & 7.78 & 98.8 & 31.05 & 3.3 \\
\hline & 5 & 15 & 25 & 40 & 50 & 60 & & & 22.4 & 7.68 & 90.6 & 28.5 & 2.4 \\
\hline & 5 & 15 & 25 & 40 & 50 & 65 & & & 22 & 7.23 & 87.5 & 27.5 & 1.9 \\
\hline & 5 & 15 & 30 & 40 & 50 & 65 & & & 21.8 & 8.3 & 86 & 27 & 3.5 \\
\hline \multirow{4}{*}{$\begin{array}{l}7 \\
(\mathrm{~V}=42 \\
\text { volt })\end{array}$} & 5 & 10 & 15 & 30 & 40 & 50 & 60 & & 26.7 & 7.3 & 129.7 & 40.7 & 1.8 \\
\hline & 5 & 10 & 20 & 30 & 40 & 50 & 60 & & 26.6 & 6 & 128.4 & 40.3 & 0.7 \\
\hline & 5 & 10 & 20 & 30 & 40 & 50 & 65 & & 26.2 & 5.7 & 124.7 & 39.1 & 0.5 \\
\hline & 5 & 10 & 20 & 30 & 40 & 55 & 70 & & 25.5 & 6.3 & 118.2 & 37.1 & 1.1 \\
\hline \multirow{4}{*}{$\begin{array}{l}8 \\
(\mathrm{~V}=48 \\
\text { volt })\end{array}$} & 5 & 10 & 20 & 25 & 35 & 45 & 55 & 65 & 29.6 & 5.4 & 159 & 50 & 0.1 \\
\hline & 5 & 10 & 20 & 25 & 30 & 40 & 55 & 70 & 29.7 & 5.8 & 160.6 & 50.4 & 0.9 \\
\hline & 5 & 10 & 20 & 25 & 35 & 40 & 50 & 65 & 30.2 & 5.3 & 165.7 & 52 & 0.8 \\
\hline & 5 & 10 & 20 & 25 & 35 & 45 & 50 & 65 & 29.9 & 5.5 & 162.8 & 51.1 & 0.8 \\
\hline
\end{tabular}

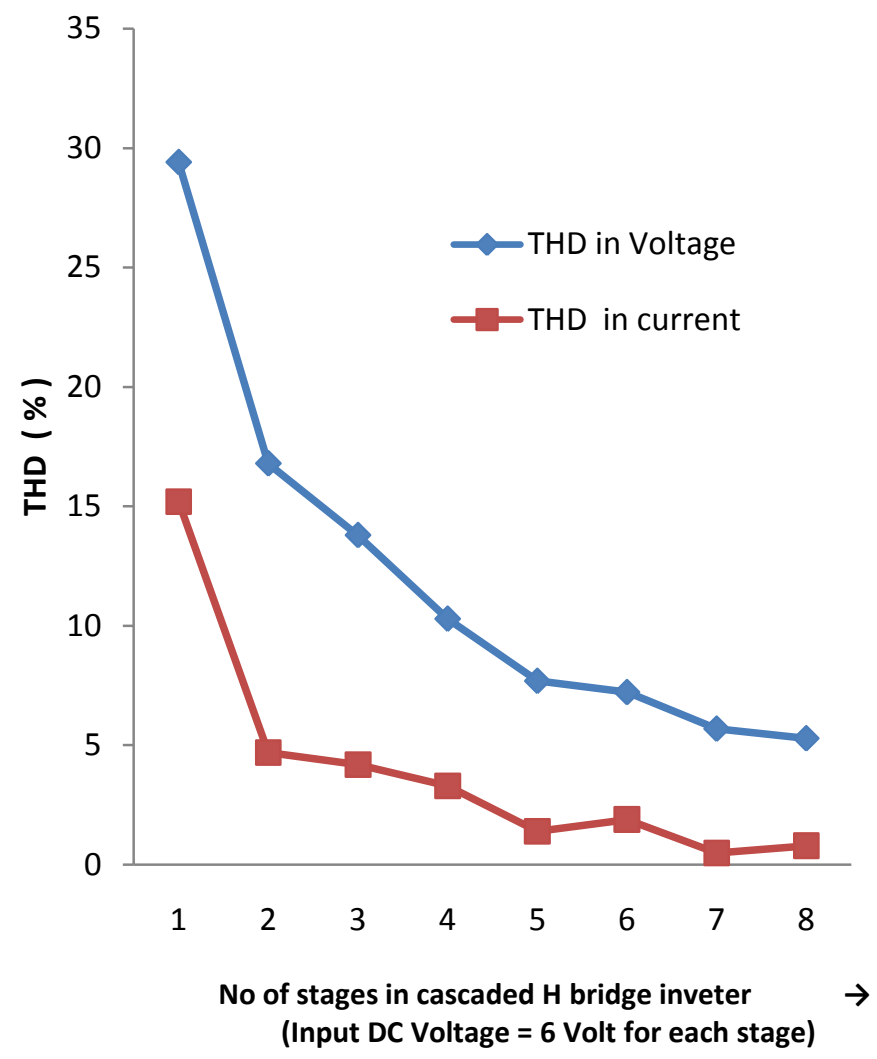

Fig. 8 Variation of THD in load voltage and current with the no. of stages in CHB inverter with Solar PV as dc source

\section{B. New Multilevel Scheme}

The newly proposed multilevel inverter circuit consists of Level Module, H-Bridge inverter, Solar PV Module as dc voltage source and RL load. This load may be an isolated

RL or a grid as shown in Fig. 9. The no. of levels of output voltage wave depends on the no. of level module used in the circuit [2].

No. of output levels

$$
n=2^{(m+1)}-1
$$

where $m$ is the no. of Level Modules used.

The no. of switches used in the circuit

$\mathrm{n}_{\mathrm{s}}=2 \mathrm{~m}+4$ 
The input dc voltage fed to kth module varies with particular module number as:

$$
V_{k}=2^{(k-1)} \cdot V_{d} \quad \text { Where } \mathrm{k}=1,2,3 \ldots \mathrm{m} \text {. }
$$

The Simulink model of the proposed circuit is shown in Fig. 10. In this new circuit, 2 Level modules (LM), 1 H-Bridge inverter, and 2 Solar PV Arrays of output voltage V1 (Vd ) and V2 (2Vd ) are used. Output wave has 7 levels and the total no. of switches used is 8 . Total dc voltage used in the circuit is $3 \mathrm{Vd}$. The gate pulse for first LM switch Q1 is a SPWM pulse having 3 pulses in each half cycle. To find the gate pulses for second LM switch Q2, this pulse is given to the clock of a negative edge triggered toggle flip flop. The gate pulses for Q1 and Q2 are shown in Fig. 11.

The Simulink Model of PV Array used in the above circuit is shown in Fig. 12 [4]. The simulation is done for $\mathrm{Vd}=2,4,6,8 \ldots 16$ Volt. Vd is defined for the case when the PV array is open circuited. It is noticed that the PV voltage decreases slightly from its open circuited value when a load is applied.

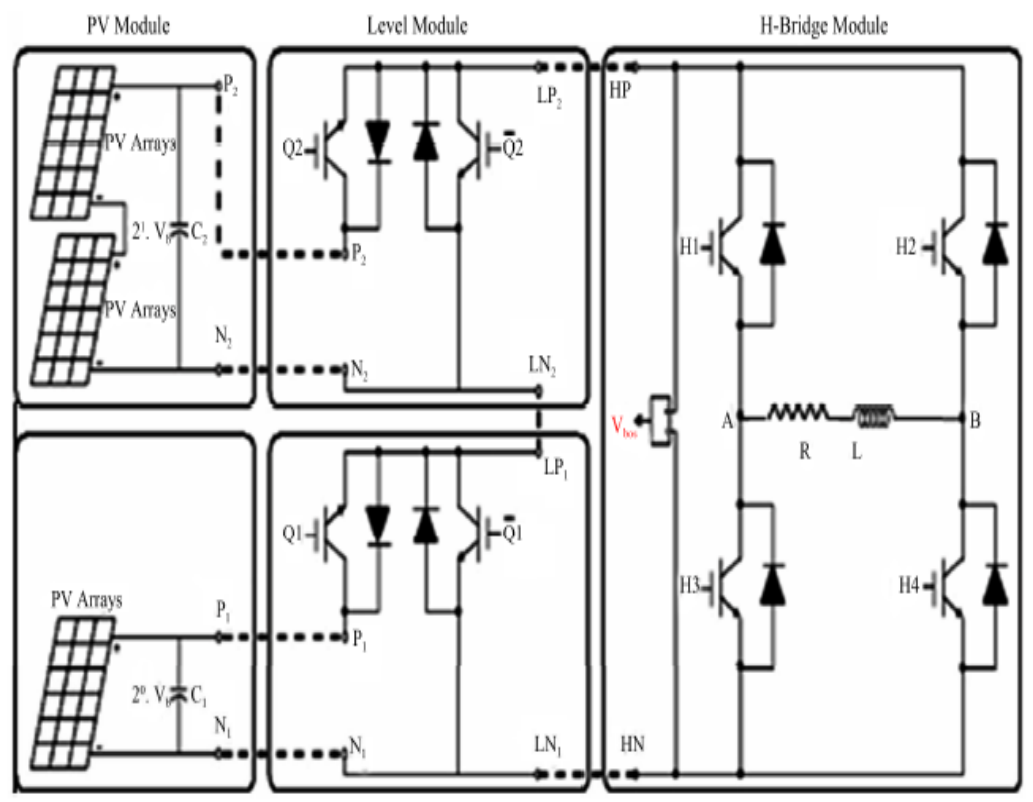

Fig. 9 Proposed Multilevel circuit with two Level Modules

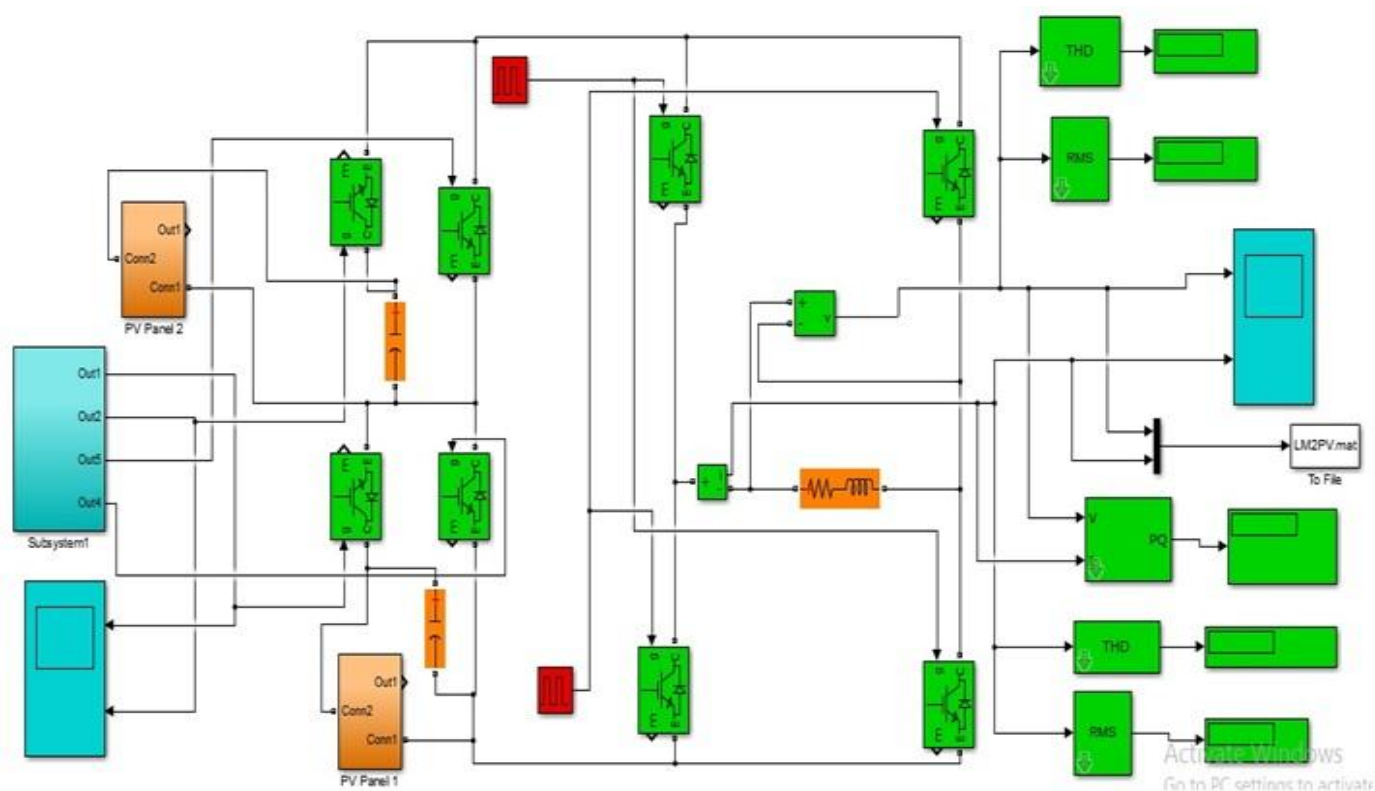

Fig. 10 Matlab Model for the proposed multi-level inverter circuit 

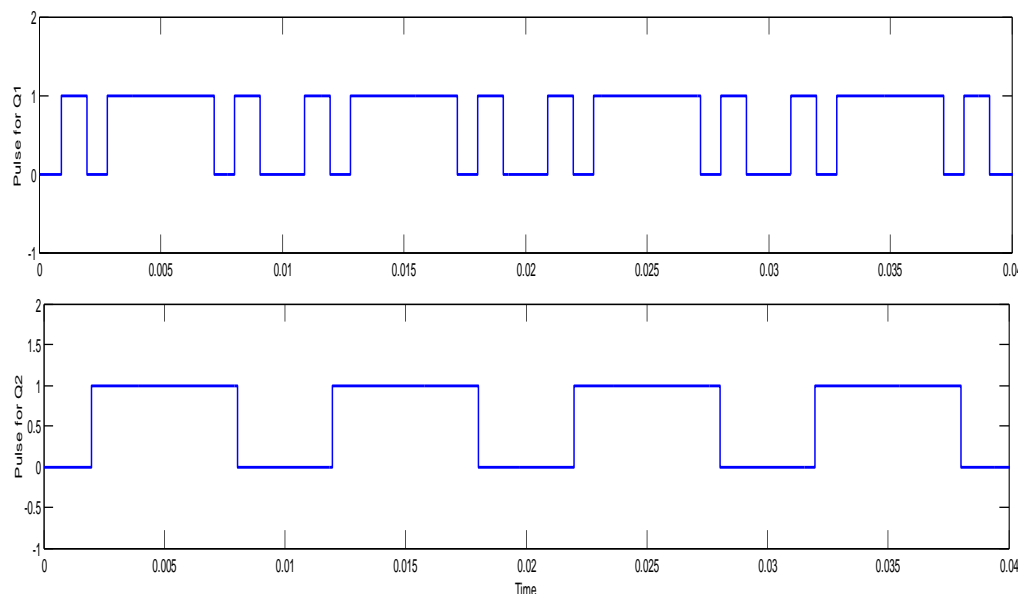

Fig. 11 Gate pulses for Switches Q1 and Q2

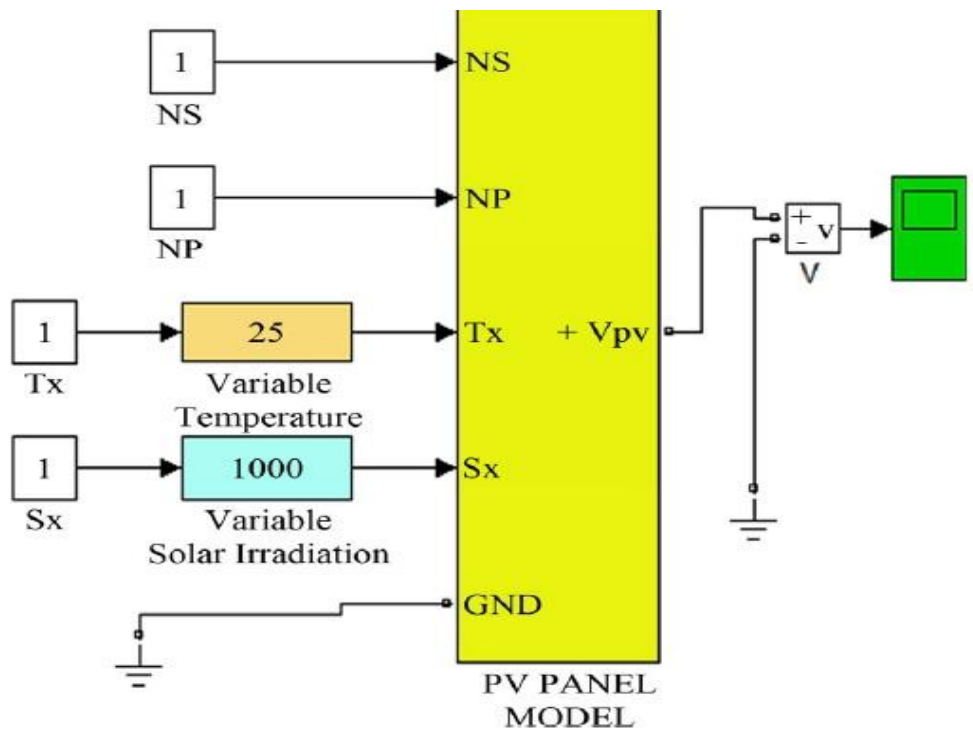

Fig. 12 PV Array Model used in the proposed circuit

\section{Simulation of New multi-level scheme with battery as a dc source:}

The simulation of the second scheme with battery as dc source is carried out in Matlab/Simulink software and the results are shown in Table III. It is observed that the THD in load voltage and current remains approximately same with the variation of input dc voltage as THD depends only upon the shape of the waveform. The load voltage \& current waveform and THD graph with the total input dc voltage are shown in the fig 13 and 14 respectively. To make the comparison of CHB scheme and new multilevel scheme at the same input dc voltage, the stages ( 6 volt per stage) are increased in CHB scheme while in multilevel scheme, input voltage is increased directly instead of increasing the stages.

The value of RL load is taken as: $\mathrm{R}=5 \Omega$ and $\mathrm{L}=5 \mathrm{mH}$.

TABLE III: Simulation Results New Multilevel Inverter Scheme With Battery As Dc Source

\begin{tabular}{|l|l|l|l|l|l|l|}
\hline S. No & $\begin{array}{l}\text { Vd } \\
\text { (Volt) }\end{array}$ & $\begin{array}{l}\text { Total de } \\
\text { Voltage (Volt) }\end{array}$ & $\begin{array}{l}\text { Active Power } \\
\text { P(W) }\end{array}$ & $\begin{array}{l}\text { Reactive Power } \\
\text { Q(VAr) }\end{array}$ & $\begin{array}{l}\text { THD } \\
\text { in Voltage (\%) }\end{array}$ & $\begin{array}{l}\text { THD } \\
\text { in current (\%) }\end{array}$ \\
\hline 1 & 2 & 6 & 3.4 & 1 & 16.14 & 7.8 \\
\hline 2 & 4 & 12 & 13.7 & 4.3 & 16.14 & 7.8 \\
\hline 3 & 6 & 18 & 30.9 & 9.7 & 16.14 & 7.8 \\
\hline 4 & 8 & 24 & 54.9 & 17.2 & 16.14 & 7.8 \\
\hline 5 & 10 & 30 & 85.8 & 27 & 16.14 & 7.8 \\
\hline 6 & 12 & 36 & 123.6 & 38.8 & 16.14 & 7.8 \\
\hline 7 & 14 & 42 & 168.2 & 52.8 & 16.14 & 7.8 \\
\hline 8 & 16 & 48 & 219.7 & 69 & 16.14 & 7.8 \\
\hline
\end{tabular}



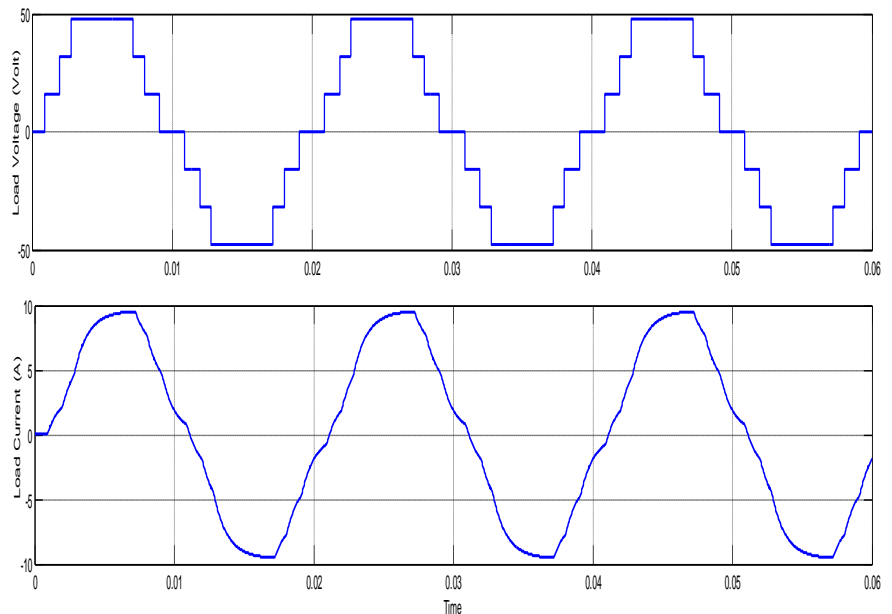

Fig. 13 Load voltage and current waveform for new multilevel inverter with battery as dc source

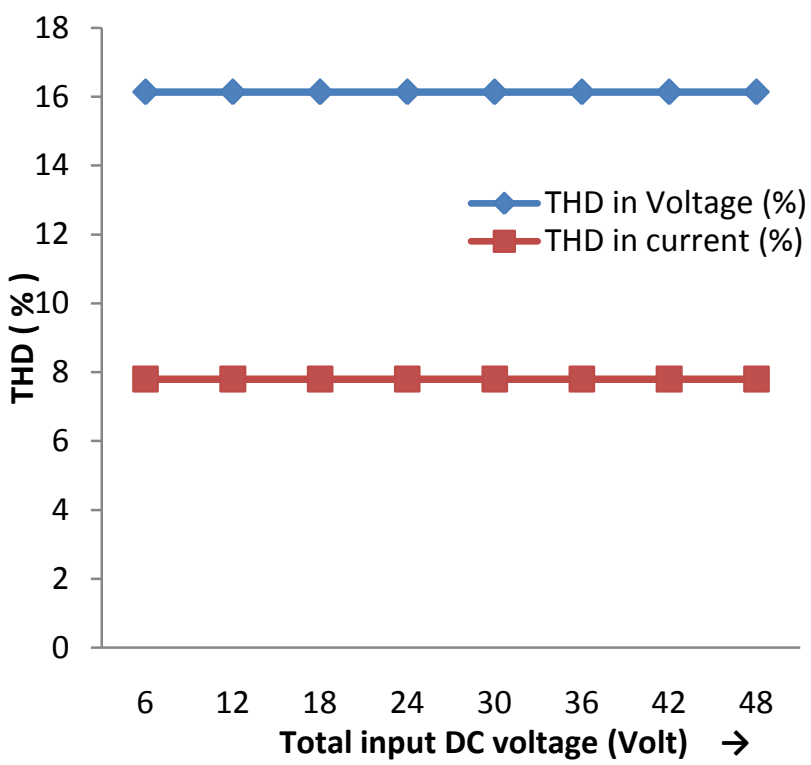

Fig. 14 Load voltage and current THD with the variation of total input dc voltage for battery as dc source

\section{Simulation of New multi-level scheme with solar PV as a dc source:}

Now the same simulation is repeated after replacing battery with solar PV panel and the results are shown in Table IV. It is also observed from here that there is minor variation in load voltage and current THD. Also the voltage and current waveforms for the circuit with battery and solar PV are almost same. The load voltage / current waveform and THD graph with pure dc input voltage are shown in the fig 15 and 16 respectively.

TABLE IV: Simulation Results For New Multilevel Inverter Scheme With Solar Pv As Dc Source

\begin{tabular}{|l|l|l|l|l|l|l|}
\hline S. No. & $\begin{array}{l}\text { Vd } \\
\text { (Volt) }\end{array}$ & $\begin{array}{l}\text { Total } \\
\text { Voltage (Volt) }\end{array}$ & $\begin{array}{l}\text { Active Power } \\
\text { P(W) }\end{array}$ & $\begin{array}{l}\text { Reactive Power } \\
\text { Q(VAr) }\end{array}$ & $\begin{array}{l}\text { THD } \\
\text { in Voltage (\%) }\end{array}$ & $\begin{array}{l}\text { THD } \\
\text { in current (\%) }\end{array}$ \\
\hline 1 & 2 & 6 & 1.85 & 0.59 & 18.4 & 9.5 \\
\hline 2 & 4 & 12 & 10.35 & 3.25 & 17 & 8.6 \\
\hline 3 & 6 & 18 & 25.7 & 8.1 & 16.8 & 8.4 \\
\hline 4 & 8 & 24 & 48 & 15 & 16.7 & 8.3 \\
\hline 5 & 10 & 30 & 77 & 24.2 & 16.6 & 8.2 \\
\hline 6 & 12 & 36 & 113.1 & 35.5 & 16.57 & 8.2 \\
\hline 7 & 14 & 42 & 156 & 49 & 16.54 & 8.17 \\
\hline 8 & 16 & 48 & 205.6 & 64.6 & 16.51 & 8.15 \\
\hline
\end{tabular}



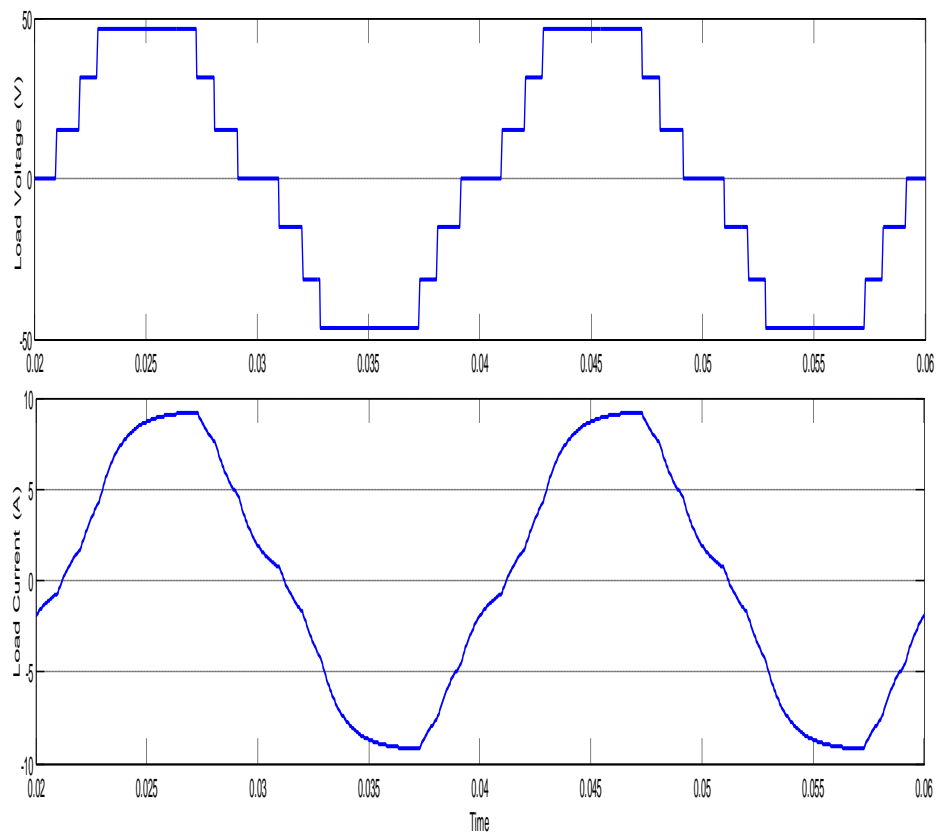

Fig. 15 Load voltage and current waveform for new multilevel inverter with solar PV as dc source

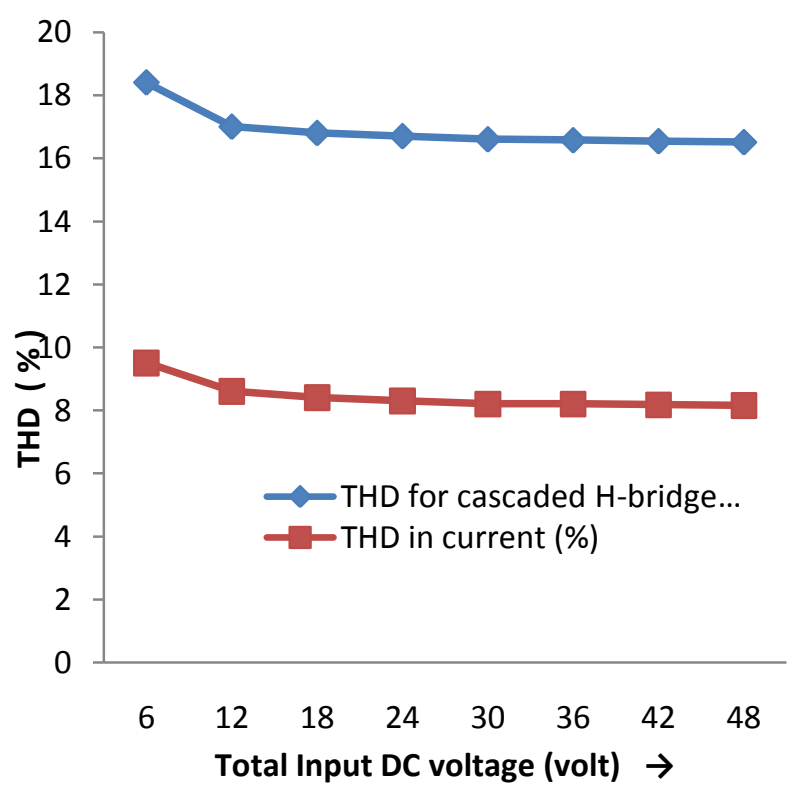

Fig. 16 Load voltage and current THD with the variation of total input dc voltage for solar PV as dc source

\section{Harmonic Content}

\section{Comparison}

The results of both the inverter scheme for battery as well as solar PV are compared for same dc input voltage. Fig 17 and 18 shows the variation of THD in load voltage and current with increasing dc input voltage (or stages). It is observed from the graphs that initially the THD is poor for CHB inverter scheme, but as the stages in CHB inverter increase the THD becomes good. However, increment in stages requires large no. of switches, which results in higher complexity, cost and losses. 


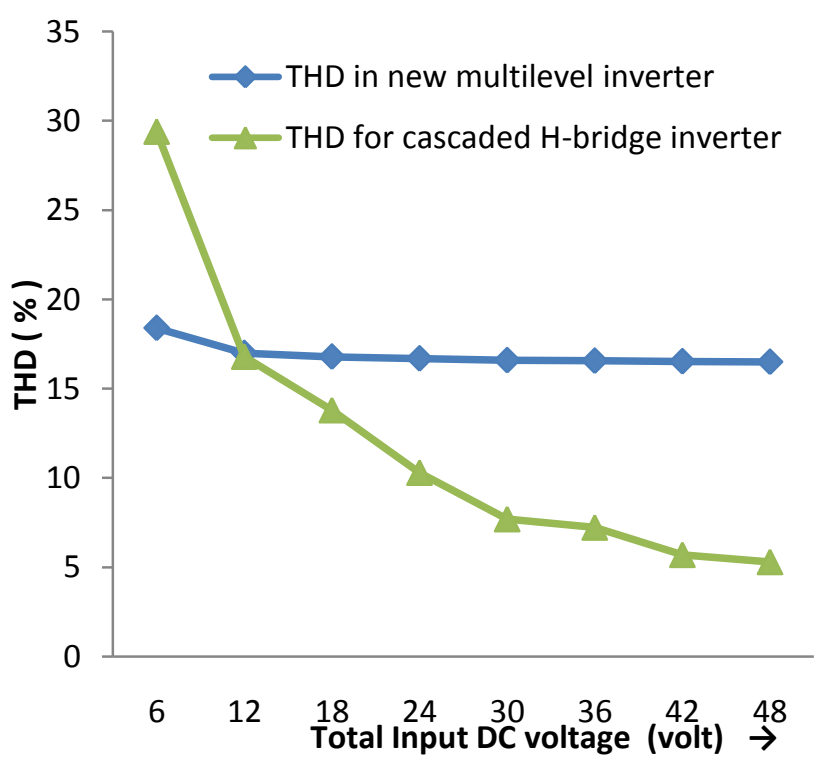

Fig. 17 Load voltage THD variation with same dc input voltage (no. of stages) for CHB scheme and new multilevel scheme

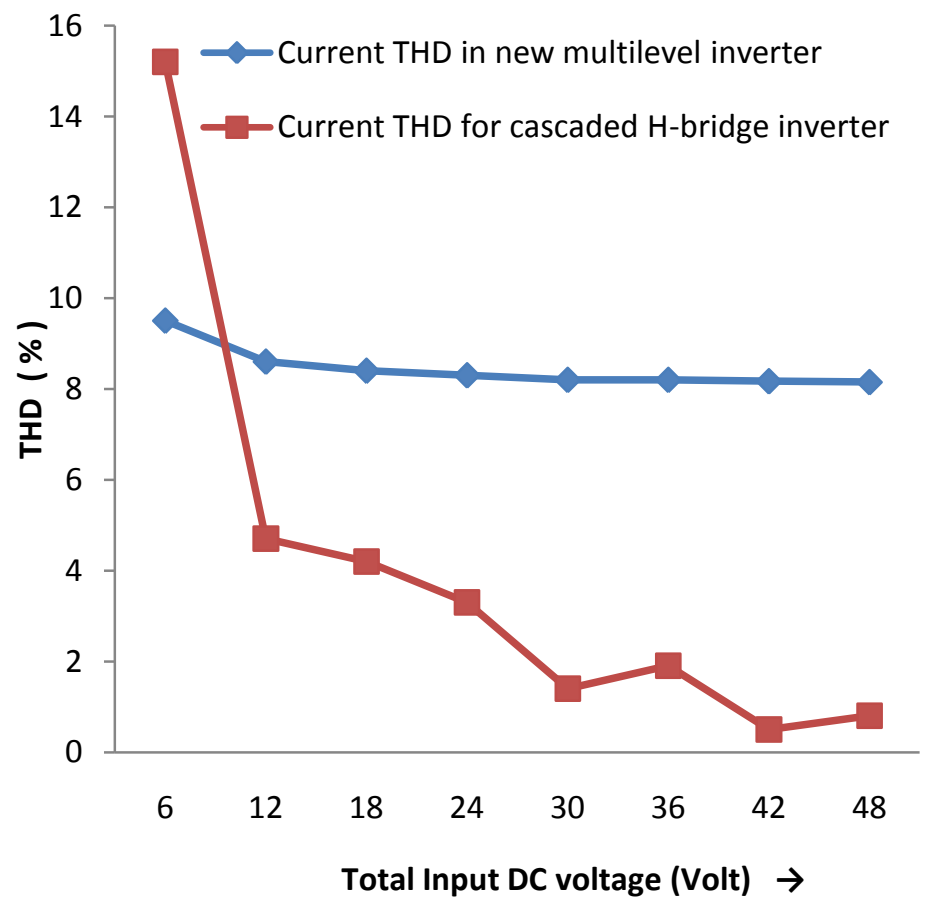

Fig. 18 Load current THD variation with same dc input voltage for both the scheme

\section{Active Power and Reactive Power Comparison}

The active and reactive power outputs for both the schemes with pure dc input are shown in Fig. 19 and 20 respectively. Both schemes give almost same performance. However, when the input source is changed to solar PV, the multilevel inverter gives improved performance. 


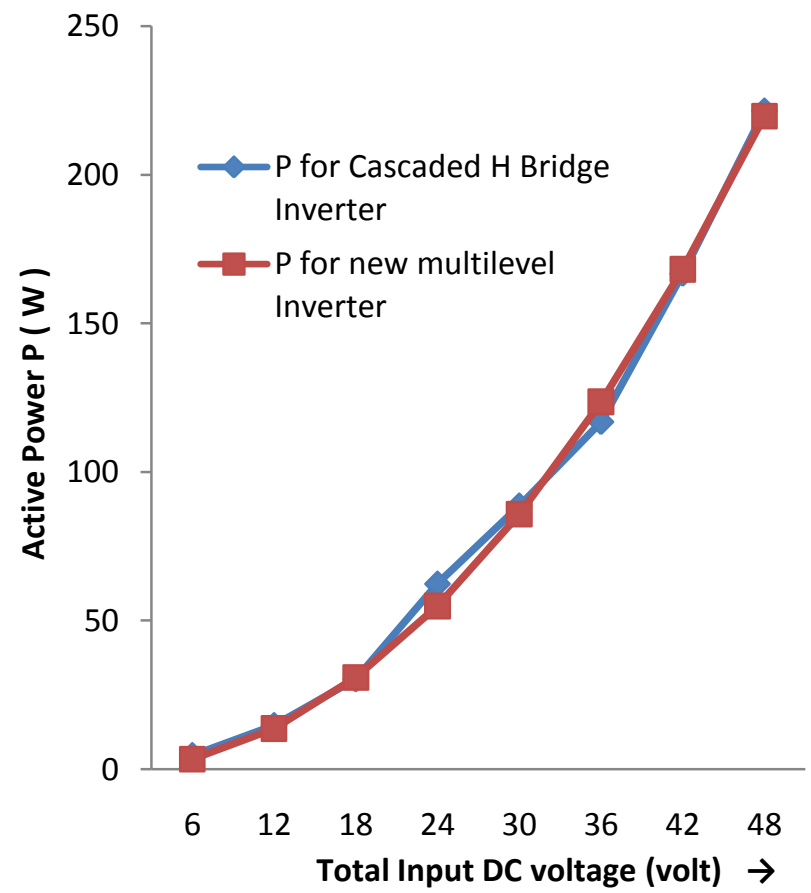

Fig. 19 Active Power P for cascaded H Bridge inverter and new multilevel inverter with battery as dc source

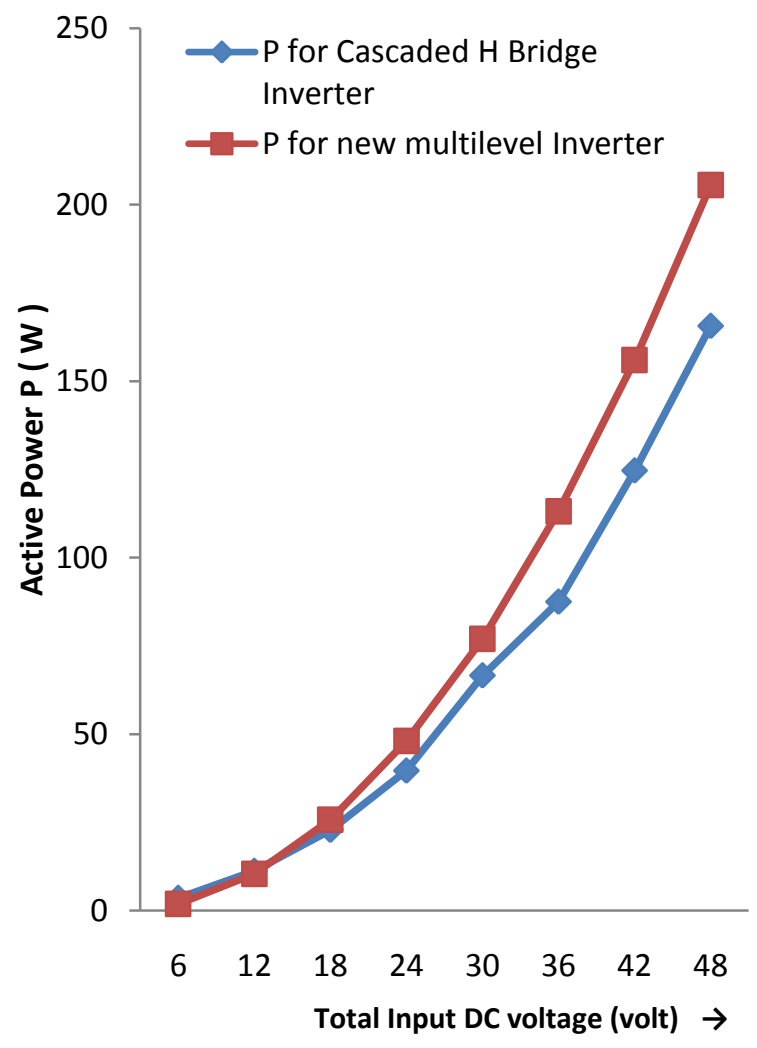

Fig. 20 Active Power P for cascaded H Bridge inverter and new multilevel inverter with solar PV as dc source 


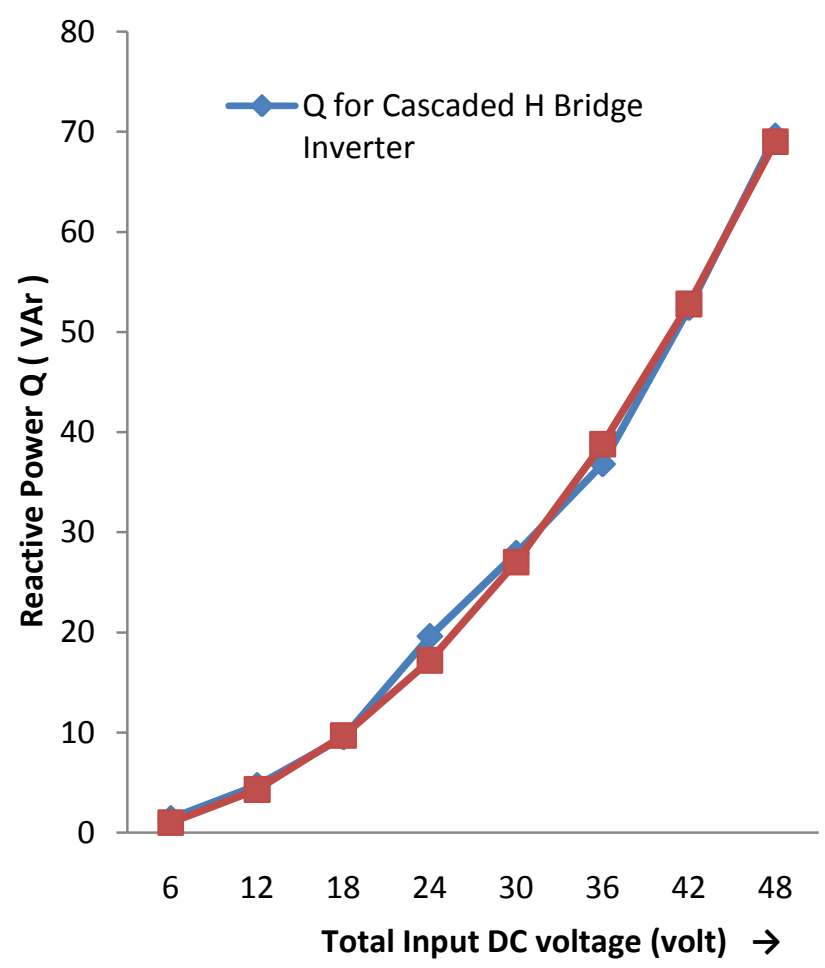

Fig. 21 Reactive Power Q for cascaded H Bridge inverter and new multilevel inverter with battery as dc source

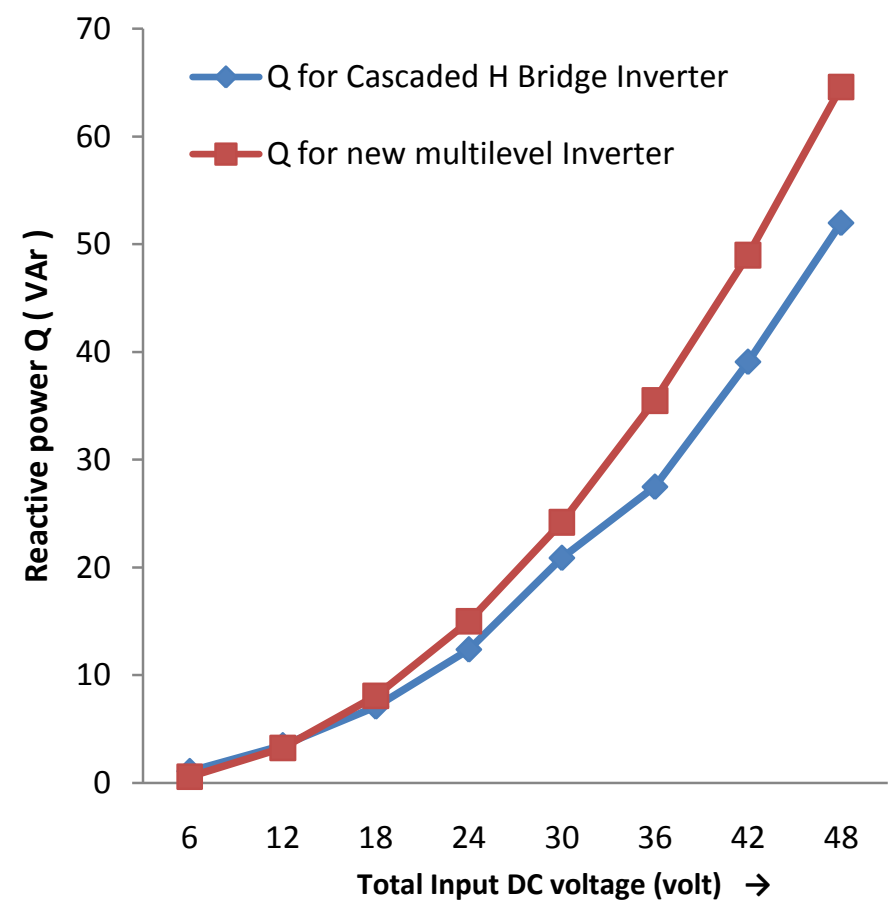

Fig. 22 Reactive Power Q for cascaded H Bridge inverter and new multilevel inverter with Solar PV as dc source

\section{Conclusion}

In this paper, THD in load voltage / current as well as Active / Reactive Power are evaluated for the two schemes using SIMULINK /MATLAB software and then compared for the same dc input voltage and same RL load with battery as well as solar PV as input dc source. 
In second scheme, spikes obtained in the output voltage are reduced by inserting the capacitors across the PV Panel. It is conclude that the THD is more but cost is less for the second scheme due to less no. of switches and hence less switching losses. Active Power and Reactive Power are more for new multilevel scheme as compare to cascaded H-Bridge Inverter.

\section{References}

[1]. E. Beser, S. Camur, B. Arifoglu, E. Kandemir Beser, "Design and application of a novel structure and topology for multilevel inverter," 2008 International Symposium On Power Electronics, Electrical Drives, Automation and Motion, Vol.1-3, pp. 969-974, Jun. 2008

[2]. E. Kandemir Beser, B. Arifoglu, S. Camur and E Beser, "Design and Application of a Single Phase Multilevel Inverter Suitable for using as a Voltage Harmonic Source", Journal of Power Electronics, Vol. 10, No.2, March 2010

[3]. [3] E. Beser, S. Camur, B. Arifoglu, E. Kandemir Beser, "A grid connected photovoltaic power conversion system with single phase multilevel inverter," Solar Energy 84 (2010), pp. 2056-2067

[4]. I.H.Altas and A.M.Sharaf, "A Photovoltaic Array Simulation Model for Matlab-Simulink GUI Environment” IEEE 2007, pp. 341345

[5]. Y. Jiang, J. A. A. Qahouq and I. Batarseh, “ Improved Solar PV Cell Matlab Simulation Model and Comparison” IEEE 2010, pp. 2770-2773

[6]. Abu Tariq, Mohammed Aslam Husain, Mohammad Ahmad and Mohd. Tariq, "Simulation and study of a grid connected Multilevel Converter (MLC) with varying DC input", IEEE Conference on Environment and Electrical Energy International Conference EEEIC 2011, Italy, Rome, May 2011

[7]. Mohammad Ahmad and B. H. Khan, "Design and Evaluation of Solar Inverter for Different Power Factor Loads", Energy and Power Engineering Journal September 2012, Scientific Research USA, Vol. 4, No. 5, pp. 324-329

[8]. Mohammad Ahmad, B H Khan; New approaches for harmonic reduction in Solar Inverter. IEEE Conference on 'Students Conference on Engineering and Systems. MNIT Allahabad, India, 2012.

[9]. J. Rodriguez, J.-S. Lai, and F. Z. Peng, "Multilevel inverters: A survey of topologies, controls and applications," IEEE Trans. Ind. Electron., Vol. 49, No. 4, pp. 724-738, Aug. 2002

[10]. G. Mahesh, Manivanna Kumar and S. Rama Reddy, "Simulation and Experimental Results of 7-Level Inverter System", Research Journal of Applied Sciences, Engineering and Technology,pp. 88-95, 2011

[11]. Jagdish Kumar, Biswarup Das and Pramod Agarwal, "Harmonic Reduction Technique for a Cascade Multilevel Inverter", International Journal of Recent Trends in Engineering, Vol 1, No. 3, May 2009 http://www.mathworks.com 